\title{
Classification of product life cycle cluster to improve the performance of SMEs apple chips
}

\author{
1, ${ }^{*}$ Novia, C., ${ }^{2}$ Santoso, I., ${ }^{3}$ Soemarno, S. and ${ }^{2}$ Astuti, R. \\ ${ }^{1}$ Departement of Informatics Engineering, Faculty of Engineering, Nurul Jadid University, Probolinggo, \\ East Java, Indonesia \\ ${ }^{2}$ Department of Agro Industrial Technology, Faculty of Agricultural Technology, Brawijaya University, \\ Malang, East Java, Indonesia \\ ${ }^{3}$ Department of Soil Science, Faculty of Agricultural, Brawijaya University, Malang, East Java, Indonesia
}

Article history:

Received: 4 May 2020

Received in revised form: 18 May 2020

Accepted: 31 May 2020

Available Online: 8 July 2020

Keywords:

Cluster,

Product life cycle,

Performance

DOI:

https://doi.org/10.26656/fr.2017.4(6).208

\begin{abstract}
Improved performance of apple chip SMEs in Malang Raya is strongly influenced by groups based on the product life cycle classification. The purpose of this study was to classify apple chip SMEs based on the results of the classification at the product life cycle stage, determine the prediction of apple chip sales and improve the performance of apple chip SMEs in Malang Raya. The research location was in Malang Raya area which consists of Malang Regency, Malang City, and Batu City. Data collection was obtained from thirty-one respondents who were the owners of apple chips SMEs in Malang Raya. Data analysis for cluster classification used the product life cycle stage and performance improvement using artificial neural networks for prediction of sales production and determination of dominant variables based on Cronbach's alpha and dominant indicators based on corrected item-total correlations. The results showed that stage 1 was 2 SMEs, stage 2 was 16 SMEs, stage 3 was 11 SMEs and stage 2 was SMEs. Improving the performance of apple chip SMEs in Malang Raya through sales predictions in 2019-2023 is more focused on improving innovation through the ability to see the development of consumer tastes and follow the development of technology related to product processing and marketing.
\end{abstract}

\section{Introduction}

The development of SMEs in Indonesia is considered very rapid and varied. There are several sectors that form the basis of SMEs, such as agriculture, fisheries, marine, animal husbandry, processing industry, etc. One sector that is considered quite promising is the manufacturing industry (Purnomo and Hadi, 2017). The fruit processing industry is one of the industries that are growing rapidly in Indonesia because Indonesia is known as a tropical country that can produce a variety of tropical fruits that cannot grow well in subtropical countries (guava, salak, durian and so on), besides that Indonesia is also able to produce fruits such as in subtropical countries (oranges, grapes, and apples). The fruit processing industry in Indonesia is very diverse, one of them is the processed industry from apples.

Apples have added value when processed into processed foods and drinks. One of the processed apple food products that can be made is apple chips. Apple chips are processed snacks made from apples that are most in-demand by consumers because they are typical souvenirs of Malang City (Mallini et al., 2015). The development of the fruit chip industry requires business players to continue to improve the competitiveness of the products they produce in the competitive global market. Production of the apple processing industry is currently still largely dependent on market demand. During holidays, market demand will increase, but demand decreases during normal days so that many industries reduce the amount of production due to reduced market demand (Wati et al., 2014). Consumer demand sometimes cannot be fulfilled by apple processed companies due to limited inventory in the finished product warehouse during the holiday season (Syam et al., 2014).

The majority of processed apple producers in Malang Raya are SMEs, although SMEs performance is quite large, it turns out that the monthly production is not 
well planned. Even in a year, the production can be below the normal capacity available. Likewise, matters relating to sales and marketing, the fact is that consumers of SME products in Malang are still limited to local markets with products that do not yet have an Indonesian National Standard license (Latifah, 2016).

Factors that influence the performance of SMEs are influenced by the business environment both inside and outside the organization which affects the sustainability of the organization (Crijns and Ooghi, 1996). The business environment is considered to play an important role in the growth of SMEs (Delmar and Wiklund, 2008). Factors in business are known as the internal environment and factors outside the business are the external environment. The growth of the internal and external environment is important for the growth of SMEs (Beck and Demirguc-Kurt, 2006). The growth of SMEs will be affected negatively or positively by changes in the business environment (Zhang et al., 2014).

The development of SMEs requires a strategy so that the goals set can be achieved properly in accordance with its portion. One of the strategies undertaken for the development of SMEs is through a cluster system. The condition of each cluster is influenced by various factors in which the cluster develops, such as cultural, social, and historical factors, the level of education of the business owner, the availability of infrastructure, the composition of business actors, and others. An industrial cluster has a role in developing industrial competitiveness, namely by increasing cluster productivity (efficiency), encouraging and accelerating the innovation of each cluster, and facilitating cluster commercialization (Porter, 2008). Based on this, it is necessary to identify the life cycle phase of the industrial cluster to ascertain its basic conditions. The results of this assessment can be used as a basis for strategies to improve current conditions and then determine appropriate policy interventions for cluster development (Handayani et al., 2012). This is in accordance with the theory of Kotler and Keller (2009) which states that each stage of the life cycle requires a different strategy, one of the marketing strategies is the product strategy.

Performance or success is sometimes defined in terms of making progress towards the goal of strategic, but most of the time the only achievement repeated at several levels of operational goals that are set before or policy of internal performance (Turi et al., 2014). Measuring the performance of SMEs is not like measuring performance in large, established companies. SMEs need an indicator to measure their performance in maintaining their existence and expanding their business.
Therefore, it is necessary to identify the factors that influence performance measurement in SMEs as a basis for evaluating performance improvement (Anggadwita and Mustafid, 2014). The method used in this research is to predict performance development through sales predictions using Artificial Neural Networks (ANN). ANN models are more efficient and effective than traditional statistical forecasting models ( $\mathrm{Yu}$ et al., 2011). ANN is a tool that is used in general and is applied to predict, classify, and cluster. This is evident in the results of research conducted by Todorov et al. (2013) on the development of contemporary food product technology shows the potential application of the ANN method to be used to solve various scientific and production problems in the field of food technology. The use of these methods can influence the development of more efficient, safe, and consumer satisfaction with products and can reduce production costs. The purpose of this study was to classify apple chip SMEs based on the results of the classification at the product life cycle stage, determine the prediction of apple chip sales and improve the performance of apple chip SMEs in Malang Raya.

\section{Materials and methods}

This research was conducted in the Malang Raya which included; Malang Regency, Malang City, and Batu City. Data collection was carried out on 31 respondents who are the owners of apple chip SMEs in Malang Raya, consisting of 5 apple chip SMEs in Malang Regency, 6 apple chip SMEs in Malang City, and 20 apple chip SMEs from Batu City. Data analysis for cluster classification uses the Product Life Cycle stage which consists of four stages namely; introduction, growth, maturity, and decline. The analysis predicted an increase in sales using artificial neural networks while improving the performance in terms of dominant performance variables (Cronbach alpha's value). The SMEs performance factors used in this study refer to the results of the research by Anggadwita and Mustafid (2014) including; aspects of entrepreneurship, HR competence, innovation, and sustainability. The performance variable in this study uses a 5-point Likert scale and the data collection uses a questionnaire.

\section{Results and discussion}

\subsection{The Product Life Cycle (PLC) stage classification} cluster

The PLC stage classification for 31 SMEs apple chips in Malang Raya is shown in Table 1.

Table 1 shows the PLC classification at stage 1 (introduction) of 2 SMEs, stage 2 (growth) of 16 SMEs, 
Table 1. Classification of PLC stage for SMEs apple chips in Malang Raya

\begin{tabular}{|c|c|c|c|c|}
\hline Stage & SMEs & Production & Sales volume & Times production \\
\hline \multirow{2}{*}{$\begin{array}{c}\text { stage } 1 \\
\text { (introduction) }\end{array}$} & SMEs 4 & 1 & 1 & 1 \\
\hline & SMEs 20 & 1 & 1 & 1 \\
\hline \multirow{16}{*}{$\begin{array}{c}\text { Stage } 2 \\
\text { (growth) }\end{array}$} & SMEs 1 & 1 & 2 & 2 \\
\hline & SMEs 3 & 2 & 3 & 2 \\
\hline & SMEs 5 & 1 & 3 & 2 \\
\hline & SMEs 11 & 2 & 4 & 2 \\
\hline & SMEs 12 & 1 & 4 & 2 \\
\hline & SMEs 13 & 2 & 4 & 2 \\
\hline & SMEs 16 & 1 & 4 & 2 \\
\hline & SMEs 17 & 1 & 3 & 2 \\
\hline & SMEs 18 & 1 & 3 & 2 \\
\hline & SMEs 19 & 2 & 4 & 2 \\
\hline & SMEs 21 & 1 & 4 & 2 \\
\hline & SMEs 22 & 1 & 3 & 2 \\
\hline & SMEs 23 & 2 & 4 & 2 \\
\hline & SMEs 24 & 1 & 2 & 2 \\
\hline & SMEs 28 & 2 & 4 & 2 \\
\hline & SMEs 31 & 2 & 3 & 2 \\
\hline \multirow{11}{*}{$\begin{array}{c}\text { Stage } 3 \\
\text { (maturity) }\end{array}$} & SMEs 2 & 2 & 2 & 3 \\
\hline & SMEs 7 & 3 & 2 & 3 \\
\hline & SMEs 8 & 2 & 2 & 3 \\
\hline & SMEs 9 & 3 & 3 & 3 \\
\hline & SMEs 14 & 1 & 2 & 3 \\
\hline & SMEs 15 & 1 & 3 & 3 \\
\hline & SMEs 25 & 3 & 2 & 3 \\
\hline & SMEs 26 & 2 & 2 & 3 \\
\hline & SMEs 27 & 2 & 3 & 3 \\
\hline & SMEs 29 & 2 & 3 & 3 \\
\hline & SMEs 30 & 2 & 3 & 3 \\
\hline \multirow{2}{*}{$\begin{array}{c}\text { Stage } 4 \\
\text { (decline) }\end{array}$} & SMEs 6 & 4 & 3 & 4 \\
\hline & SMEs 10 & 3 & 2 & 4 \\
\hline
\end{tabular}

Note: Production $(1=0-10$ quintals, $2=11-20$ quintals, $3=21-30$ quintals, $4=>30$ quintals $)$; sales volume $(1=0-25 \%, 2=25-$ $50 \%, 3=51-75 \%, 4=76-100 \%)$; times production $(1=0-5$ years, $2=6-10$ years, $3=11-15$ years, $4=>15$ years $)$

stage 3 (maturity) of 11 SMEs, and stage 4 (decline) of 2 SMEs. Product strategy used at the introductory stage (introduction) to offer basic products, at the stage of growth (growth) offer extension product, service, warranty, at the stage of maturity (maturity) diversification of brands and models, the stage of decline (declining) the type of product that is weak. Cluster development must be balanced with a good corporate strategy because it will have a direct impact on increasing competition. Intense competition in the business becomes the main challenge for the company in carrying out its production activities. Companies are required to think creatively and have a competitive strategy by producing quality goods, cheap and fast compared to competitors (Munawir et al., 2016).

Figure 1 shows the classification of SME stages based on PLC curves with sales and times production divided into 4 stages of the product life cycle. The product life cycle consists of an introduction phase, a growth stage, a maturity stage, and a decline stage. At the introduction stage, the product is not popular and cannot generate much profit. Marketing costs may be high to test the market and build distribution channels. At the growth stage, the product starts to make a profit, increasing sales quickly with some costs on marketing especially building brands. Competitors start to enter the market, not infrequently most of them attract the market. This stage can also be called take-off stage. When profits start to decline, it's a sign of the stage of maturity. In the maturity stage, sales continue to increase until it stabilizes but at a profit rate decreases, due to price competition. The product reaches its peak at this stage, most companies struggle aggressively to maintain their market share. This competition is very intense, unfortunately, SMEs will die one by one. During the decline phase, profits begin to decline gradually, each company must manage carefully. There are not many choices to choose now; taking most of the product before leaving or expanding the market by using a marketing mix strategy to extend product life (Cao and Folan, 2012) 


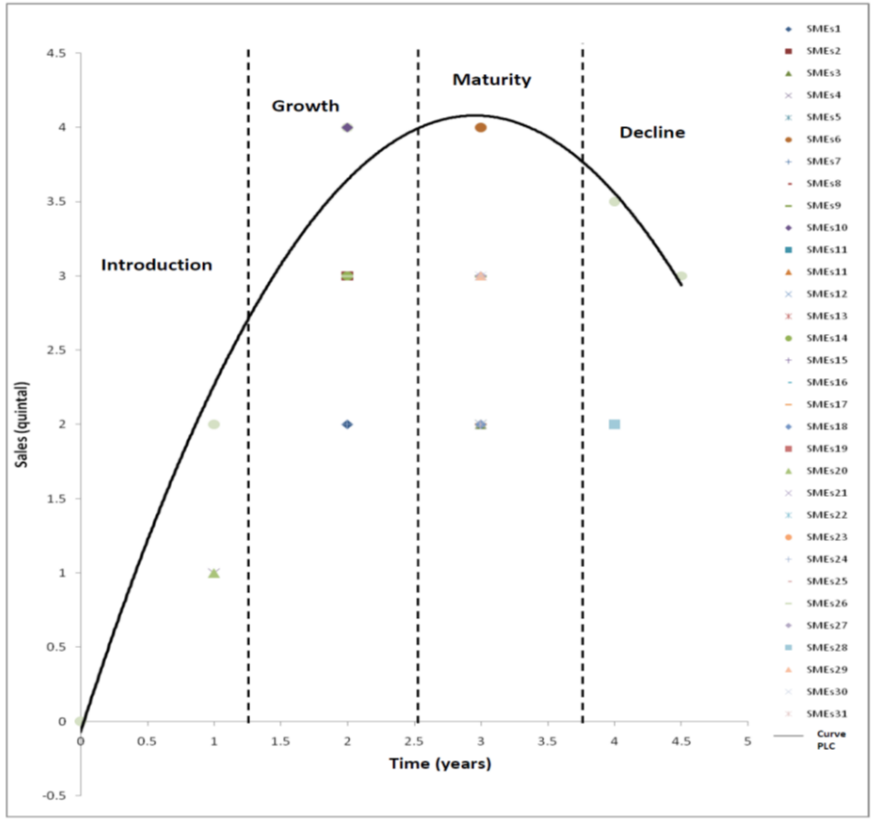

Figure 1. Classification of stages of apple chips SMEs based on curves PLC

The product life cycle is the period of time in which an item is developed, brought to the market and finally released from the market (Kamthe and Verma, 2013). In general, each product goes through four stages: introduction, growth, maturity, and decline (Barsila et al., 2015). The product life cycle is an important concept that can provide information to managers about the concept of dynamic competition. PLC models and simulations can be used to identify several factors that influence customer satisfaction and loyalty with new products (Kazemi et al., 2011). Internal key contributors for each PLC stage can help managers to understand the performance or performance of their developing markets (Khan and Billah, 2013) as well as fundamental variables that can influence business strategy and performance (Chen et al., 2016). At different stages of the PLC, demand will affect a company's absorptive capacity and hence the performance of its technological innovations (Zou et al., 2016).

\subsection{Performance}

Before analyzing the performance improvement of SME apple chips in Malang, it is necessary to analyze the number of sales and their predictions. Data on the number of sales was taken from 16 SMEs included in the stage 2 PLC cluster, namely stage growth. The reason for the prediction of product sales was done at stage 2 (growth), because at this stage sales continued to increase until it becomes stable but at a profit level has decreased, because of price competition and most companies struggle aggressively to maintain their market share (Cao and Folan, 2012). This finding is in line with the results of research from Santoso (2016) which states that the factors with the highest priority should be considered in the formulation of a product development strategy in a growth position.

Table 2 shows the highest sales of apple chips in Malang during 2014-2018 in 2018 which reached 1,390 quintals, while the lowest in 2014 which was $1,132.16$ quintals. Calculation of forecasting sales of apple chips by SMEs apple chips in Malang Raya during 2019-2023 uses artificial neural network (ANN) method with 12 input layers, 12 hidden layers, 1 output layer, and 1000 iterations. The ANN calculation results are shown in Table 3.

Table 2. The sale of apple chips in Malang Raya during 20142018

\begin{tabular}{|c|c|c|c|c|c|}
\hline Month & 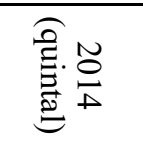 & 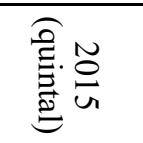 & 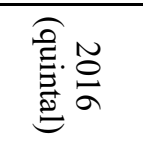 & 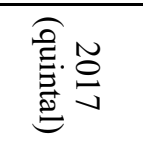 & 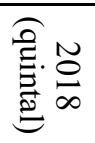 \\
\hline January & 102.22 & 107.6 & 113.26 & 119.23 & 125.5 \\
\hline February & 82.27 & 86.59 & 91.15 & 95.95 & 101 \\
\hline March & 74.12 & 78.02 & 82.13 & 86.45 & 91 \\
\hline April & 80.64 & 84.88 & 89.35 & 94.05 & 99 \\
\hline May & 96.11 & 101.17 & 106.5 & 112.1 & 118 \\
\hline June & 127.06 & 133.75 & 140.79 & 148.2 & 156 \\
\hline July & 118.92 & 125.18 & 131.77 & 138.7 & 146 \\
\hline August & 90.41 & 95.17 & 100.18 & 105.45 & 111 \\
\hline September & 78.19 & 82.31 & 86.64 & 91.2 & 96 \\
\hline October & 79.41 & 83.59 & 87.99 & 92.63 & 97.5 \\
\hline November & 88.78 & 93.45 & 98.37 & 103.55 & 109 \\
\hline December & 114.03 & 120.03 & 126.35 & 133 & 140 \\
\hline Total & $1,132.16$ & $1,191.74$ & $1,254.48$ & $1,320.51$ & 1,390 \\
\hline
\end{tabular}

Table 3. Predict the sale of apple chips in Malang Raya during 2019-2023

\begin{tabular}{|c|c|c|c|c|c|}
\hline Month & 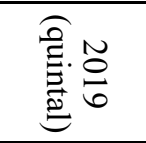 & 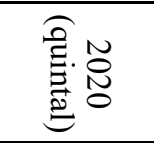 & 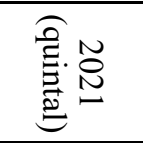 & 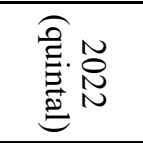 & 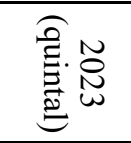 \\
\hline January & 132.96 & 139.01 & 143.51 & 145.44 & 145.84 \\
\hline February & 107.1 & 121.81 & 139.09 & 144.92 & 145.79 \\
\hline March & 99.07 & 117.34 & 138.47 & 144.91 & 145.79 \\
\hline April & 108.95 & 126.00 & 141.55 & 145.35 & 145.84 \\
\hline May & 128.56 & 139.53 & 144.74 & 145.73 & 145.88 \\
\hline June & 150.44 & 147.23 & 145.89 & 145.86 & 145.90 \\
\hline July & 146.39 & 145.26 & 145.35 & 145.77 & 145.89 \\
\hline August & 121.21 & 134.54 & 143.45 & 145.56 & 145.86 \\
\hline September & 106.81 & 127.91 & 142.59 & 145.51 & 145.86 \\
\hline October & 108.94 & 131.57 & 143.74 & 145.66 & 145.88 \\
\hline November & 124.70 & 140.68 & 145.18 & 145.82 & 145.90 \\
\hline December & 143.12 & 144.88 & 145.67 & 145.87 & 145.90 \\
\hline Total & $1,478.24$ & $1,615.751$ & $1,719.25$ & $1,746.40$ & $1,750.34$ \\
\hline $\begin{array}{l}\text { Error }=0,0 \\
\mathrm{MSE}=2,9 \\
\mathrm{MAE}=1,2\end{array}$ & $\begin{array}{l}34732 \\
+3442 \\
71966\end{array}$ & & & & \\
\hline
\end{tabular}


Table 3 shows the MAE value of 1.27 and the MSE value of 2.94. MSE value is said to be very good if the resulting error value is less than $10 \%$, good if the resulting error value is between $10 \%-25 \%$, while the value is not good if the resulting error value is more than $25 \%$. The result of testing with 1000 iteration produced an error value of $0.04(4 \%)$, meaning that the ANN results were categorized very well so that the best parameters obtained showed that this model was suitable for forecasting the sale of apple chips with MSE value of good value. ANN analysis results showed an increase in sales of apple chips during 2019-2023 by 221.2 quintals (15.6\%) from 2018 as many as $1,478.24$ quintals to 2023 by $1,750.34$. Predictions of increasing sales are certainly going to have a direct impact on improving the performance of the SMEs apple chips in Malang. Research on performance improvement on apple chips SMEs in Malang is focused on four main variables namely; entrepreneurship, human resource competence, innovation, and sustainability. Variable values and performance indicators of SMEs apple chips in Malang Raya are shown in Table 4.

Table 4 shows the biggest value or dominant variable in improving the performance of apple chip SMEs in Malang is the innovation variable by 0.763 , then the next variable is sustainability at 0.760 , entrepreneurship at 0.735 , and human resource competency at 0.681 .

Improved performance on the innovation variable requires that SME apple chips must have the ability to see the development of consumer tastes following the development of technology related to product processing and marketing with a value of 0.712. Improved performance in the variable of sustainability requires SMEs apple chips can improve the welfare of employees each year with a value of 0806 , has the ability da lam manage waste production in order not to pollute the environment with a value of 0.558 , and increasing profits each year with a value of 0483 .

Improved performance on the entrepreneurial variable requires that the entrepreneur of apple chips SMEs must know the dimensions of the business market they live with a value of 0.711 , a consistent and committed person in entrepreneurship with a value of 0.637 , and have business management knowledge and manage businesses with a value of 0.407. Improved performance on the human resource competency variable requires that SME entrepreneurs understand the business strategy for the business they are running with a value of 0.668 , have a good ability to communicate with people around them with a value of 0.520 and have the ability to formulate and solve various kinds of problems in business with a value of 0.387 .

Lin et al. (2010), innovation capabilities consist of product innovation, process innovation, marketing innovation, service innovation, and administrative innovation. The results of the study of Yahya et al. (2011) showed that the characteristics of a more innovative SME manufacturing company were considered different compared to a SME manufacturing company that was less innovative, whereas Hilmi et al. (2010) state that innovative processes have a significant relationship with SME performance. Sok and O'Cass (2011) found that there is a significant influence between resources and innovation capability on performance based on innovation. Parrilli and Elola (2012) found that

Table 4. Variable values and performance indicators of SMEs apple chip in Malang Raya

\begin{tabular}{|c|c|c|c|}
\hline Variable & Cronbach's & Indicator & Corrected Item-Total \\
\hline \multirow{3}{*}{ Entrepreneurship } & \multirow{3}{*}{0.735} & $\begin{array}{l}\text { Entrepreneurship of apple chips SMEs knows the dimensions of the } \\
\text { business market they live }\end{array}$ & 0.711 \\
\hline & & $\begin{array}{l}\text { Entrepreneurship SMEs apple chips is a consistent and committed } \\
\text { individual in entrepreneurship }\end{array}$ & 0.637 \\
\hline & & Entrepreneurs for apple chips have knowledge of business management & 0.401 \\
\hline \multirow{3}{*}{$\begin{array}{l}\text { Human Resource } \\
\text { Competencies }\end{array}$} & \multirow{3}{*}{0.681} & $\begin{array}{l}\text { Entrepreneurs for apple chips SMEs must have the ability to formulate } \\
\text { and solve various problems in the business }\end{array}$ & 0.387 \\
\hline & & $\begin{array}{l}\text { SME entrepreneurs understand the business strategy for the business } \\
\text { they are running }\end{array}$ & 0.668 \\
\hline & & $\begin{array}{l}\text { Entrepreneurs in apple chips have a good ability to communicate with } \\
\text { people around them }\end{array}$ & 0.52 \\
\hline \multirow{2}{*}{ Innovation } & \multirow{2}{*}{0.763} & $\begin{array}{l}\text { Apple chips SMEs must have the ability to see the development of } \\
\text { consumer tastes }\end{array}$ & 0.712 \\
\hline & & $\begin{array}{l}\text { Apple chips SMEs must keep abreast of technological developments } \\
\text { related to product processing and marketing }\end{array}$ & 0.712 \\
\hline \multirow{3}{*}{ Sustainability } & \multirow{3}{*}{0.76} & Apple chips SMEs can increase profits every year & 0.483 \\
\hline & & Increased employee welfare every year & 0.806 \\
\hline & & $\begin{array}{l}\text { Apple chips SMEs are able to manage the waste from the production so } \\
\text { that it does not pollute the environment }\end{array}$ & 0.558 \\
\hline
\end{tabular}


the ability of innovation leads to company performance. Saunila (2014) shows that the three aspects of innovation ability, namely R\&D, organizational learning, and leadership positively influence the performance of SMEs.

Innovative SMEs are more likely to have a shared vision, be open-minded, and learn from crises, able to reflect on their experiences (Saunders et al., 2014). The practice of innovation openly can improve innovation performance (Ebersberger et al., 2012) and competitiveness (Chesbrough and Brunswicker, 2014; Rossi, 2015). Product innovation is a major source of competitive advantage and a driver of marketing and corporate financial performance (Calisir et al., 2013; Molina et al., 2014). The ability of innovation has a significant influence on improving the performance and competitive advantage of SMEs (Wu and Sivalogathasan, 2013).

\section{Conclusion}

The results showed that the SME cluster of apple chips based on PLC stage classification consisted of four stages namely; stage 1 (introduction) of 2 SMEs, stage 2 (growth) of 16 SMEs, stage 3 (maturity) of 11 SMEs and stage 4 (decline) of 2 SMEs. The prediction of the number of apple chip sales during 2019-2023 increased by 221.2 quintals $(15.6 \%)$ and an increase in the performance of apple chip SMEs in Malang is more focused on the innovation variable through the ability to see the development of consumer tastes and follow the development of related technologies with product processing and marketing, then the variables of sustainability, entrepreneurship, and human resource competence.

\section{Conflict of interest}

The authors hereby declare no conflict of interest.

\section{Acknowledgments}

We would like to thank Department of Agro Industrial Technology, Faculty of Agricultural Technology, University of Brawijaya and Nurul Jadid University.

\section{References}

Anggadwita, G. and Mustafid, Q.Y. (2014). Identification of factors influencing the performance of small medium enterprises (SMEs). ProcediaSocial and Behavioral Sciences, 115, 415-423. https://doi.org/10.1016/j.sbspro.2014.02.448

Barsila, S.R., Devkota, N.R., Kreuzer, M. and
Marquardt, S. (2015). Effects of different stocking densities on performance and activity of cattle $\times$ yak hybrids along a transhumance route in the Eastern Himalaya. SpringerPlus, 4, 398. https:// doi.org/10.1186/s40064-015-1175-4

Beck, T. and Demirguc-Kunt, A. (2006). Small and medium-size enterprises: Access to finance as a growth constraint. Journal of Banking and Finance, 30(11), 2931-2943. https://doi.org/10.1016/ j.jbankfin.2006.05.009

Calisir, F., Gumussoy, C.A. and Guzelsoy, E. (2013). Impacts of learning orientation on product innovation performance. The Learning Organization, 20(3), 176-194. https:// doi.org/10.1108/09696471311328442

Cao, H. and Folan, P. (2012). Product life cycle: the evolution of a paradigm and literature review from 1950-2009. Production Planning and Control, 23 (8), 641-662. https:// doi.org/10.1080/09537287.2011.577460

Chen, Y.M., Liu, H.H. and Wu, H.Y. (2016). Reputation for toughness and anti-dumping rebuttals: competitive rivalry, perceived benefits, and stage of the product life cycle. Journal of Business Research, 69(6), 2145-2150. https://doi.org/10.1016/ j.jbusres.2015.12.022

Chesbrough, H. and Brunswicker, S. (2014). A fad or a phenomenon? The adoption of open innovation practices in large firms. Research-Technology Management, 57(2), 16-25.

Crijns, H. and Ooghe, H. (1996). Growth paths of medium-sized entrepreneurial companies presented at the 41th ICSB World Conference, June 16-19, 1996, p. 173-193. Stockholm, Sweden.

Delmar, F. and Wiklund, J. (2008). The effect of small business managers' growth motivation on firm growth: A longitudinal study. Entrepreneurship Theory and Practice, 32(3), 437-457. https:// doi.org/10.1111/j.1540-6520.2008.00235.x

Ebersberger, B., Bloch, C., Herstad, S. J. and Van De Velde, E.L.S. (2012). Open innovation practices and their effect on innovation performance. International Journal of Innovation and Technology Management, $9(6), \quad 1250040 . \quad \mathrm{https}: / /$ doi.org/10.1142/ S021987701250040X

Handayani, N.U., Cakravastia, A., Diawati, L. and Bahagia, S.N. (2012). A conceptual assessment model to identify phase of industrial cluster life cycle in Indonesia. Journal of Industrial Engineering and Management, 5(1), 198-228. https:// doi.org/10.3926/jiem.447

Hilmi, M.F., Ramayah, T., Mustapha, Y. and Pawanchik, 
S. (2010). Product and process innovativeness: Evidence from Malaysian SMEs. European Journal of Social Science, 16(4), 556-565.

Kamthe, M. and Verma, D.S. (2013). Product life cycle and marketing management strategies. International Journal of Engineering Research and Technology, 2 (4), 2035-2042.

Kazemi, M.A.A., Eshlaghy, A.T. and Tavasoli, S. (2011). Developing the product strategy via product life cycle simulation according to the system dynamics approach. Applied Mathematical Sciences, 5(17), 845-862.

Khan, M.M. (2013). Product life cycle strategies in emerging markets: A case study from Pakistan. Kuwait Chapter of Arabian Journal of Business and Management Review, 33(860), 1-24. https:// doi.org/10.12816/0001263

Kotler, P. and Keller, K.L. (2009). Manajemen pemasaran. Indonesia: PT Macanan Jaya Cemerlang. [In Bahasa Indonesia].

Latifah, S.W. (2016). Karakteristik pelaku ekonomi penunjang supply chain management SMES pangan di Malang. Conference on Management and Behavioral Studies, p. 206-216. Jakarta, Indonesia: Universitas Tarunmanagara.

Lin, R.-J., Chen, R.-H. and Chiu, K.K.-S. (2010). Customer relationship management and innovation capability: an empirical study. Industrial Management and Data Systems, 110(1), 111-133. https://doi.org/10.1108/02635571011008434

Mallini, L., Dania, W.A.P. and Putri, S.A. (2015). Peramalan permintaan dengan pendekatan marketing mix pada produk keripik apel menggunakan metode jaringan syaraf tiruan. Industria: Jurnal Teknologi dan Manajemen Agroindustri, 4(1), 21-30. [In Bahasa Indonesia].

Molina, A., Aranda, E., Martín, V.J. and Santos, J. (2014). Opportunities for craft consumption: analysis of the quality perceived by consumers. International Journal of Globalisation and Small Business, 6(1), 64-78. https://doi.org/10.1504/IJGSB.2014.063407

Munawir, H., Sufa, M.F. and Wigaringtyas, L.D. (2016). Strategi peningkatan kinerja rantai pasok SMEs batik dengan supply chain operation reference (SCOR). Universitas Muhammadiyah Surakarta. [In Bahasa Indonesia].

Parrilli, M.D. and Elola, A. (2012). The strength of science and technology drivers for SME innovation. Small Business Economics, 39(4), 897-907. https:// doi.org/10.1007/s11187-011-9319-6

Porter, M.E. (2008). On competition. Boston, Massachusetts, USA: Harvard Business Press.
Purnomo, C.A. and Hadi, Y. (2017). Pengukuran kinerja umkm menggunakan performance prism. Spektrum Industri, 15(2), 121-136. [In Bahasa Indonesia]. https://doi.org/10.12928/si.v15i2.7550

Rossi, M. (2015). The role of venture capital funds in financing innovation in Italy. Constraints and challenges for innovative small firms. International Journal of Globalisation and Small Business, 7(2), 162-180. https://doi.org/10.1504/ IJGSB.2015.071201

Santoso I. (2016). Integrasi analisis product life cycle dan metode ahp-topsis dalam perumusan strategi pengembangan produk. Journal of Agroindustrial Technology, 26(2), 227-235. [In Bahasa Indonesia]

Saunders, M.N., Gray, D.E. and Goregaokar, H. (2014). SME innovation and learning: the role of networks and crisis events. European Journal of Training and Development, 38(1-2), 136-149. https:// doi.org/10.1108/EJTD-07-2013-0073

Saunila, M. (2014). Innovation capability for SME success: perspectives of financial and operational performance. Journal of Advances in Management Research, 11(2), 163-175. https://doi.org/10.1108/ JAMR-11-2013-0063

Sok, P. and O'Cass, A. (2011). Achieving superior innovation-based performance outcomes in SMEs through innovation resource-capability complementarity. Industrial Marketing Management, 40(8), 1285-1293. https://doi.org/10.1016/ j.indmarman.2011.10.007

Syam, Q.N., Santoso, I. and Putri, S.A. (2014). Pengendalian persediaan apel untuk produksi minuman sari apel dengan pendekatan supply chain management (studi kasus di Brosem Malang). Fakultas Teknologi Pertanian. Universitas Brawijaya. [In Bahasa Indonesia].

Todorov, Y., Nacheva, I., Metodieva, P., Doneva, M. and Tsvetkov, T. (2013). Soft computing applications in food technology.Bulgarian Journal of Agricultural Science, 19(3), 503-507.

Turi, A., Goncalves, G. and Mocan, M. (2014). Challenges and competitiveness indicators for the sustainable development of the supply chain in food industry. Procedia-Social and Behavioral Sciences, 124, 133-141. https://doi.org/10.1016/ j.sbspro.2014.02.469

Wati, N.K., Shaleh, C. and Wachid, A. (2014). Strategi pengembangan industri pengolahan apel berbasis ekonomi lokal (studi pada dinas koperasi, SMEs, perindustrian dan perdagangan Kota Batu). Jurnal Administrasi Publik, 2(1), 102-108. [In Bahasa Indonesia]. 
$\mathrm{Wu}, \mathrm{X}$. and Sivalogathasan, V. (2013). Intellectual capital for innovation capability: a conceptual model for innovation. International Journal of Trade, Economics and Finance, 4(3), 139-144. https:// doi.org/10.7763/IJTEF.2013.V4.274

Yahya, A.Z., Othman, M.S., Othman, A.S., Rahman, I.A. and Moen, J.A. (2011). Process innovation: a study of Malaysian small medium enterprises (SMEs). World Journal of Management, 3(1), 146-156.

Yu, Y., Choi, T.M. and Hui, C.L. (2011). An intelligent fast sales forecasting model for fashion products.Expert Systems with Applications, 38(6), 7373-7379. https://doi.org/10.1016/ j.eswa.2010.12.089

Zhang, S.S., van Doorn, J. and Leeflang, P.S. (2014). Does the importance of value, brand and relationship equity for customer loyalty differ between Eastern and Western cultures? International Business Review, 23(1), 284-292. https://doi.org/10.1016/ j.ibusrev.2013.05.002

Zou, B., Guo, F. and Guo, J. (2016). Absorptive capacity, technological innovation, and product life cycle: a system dynamics model. Springer Plus, 5 (1), 1662. https://doi.org/10.1186/s40064-016-3328- 